\title{
ARTIGOS
}

\section{A HISTÓRIA COMO SACRIFÍCIO EM BLAISE PASCAL}

Luís César Guimarães Oliva*

RESUMO Este trabalho desenvolve o tema da História em Pascal, buscando constituí-lo por meio da noção teológica de sacrifício. No contexto pascaliano, a História só é relevante enquanto História Espiritual, a história da salvação dos homens escolhidos entre os condenados pela queda adâmica. Como tal, a História não pode ser regida pela temporalidade vivida ordinariamente, mas pela temporalidade da graça, que direciona todos os instantes para o ponto central, o sacrifício de Jesus Cristo. Por isso, os homens só têm esperança de salvação na medida em que se integram ao Corpo Crístico, que prossegue em sacrifício desde o início até o fim dos tempos.

Palavras-chave História, Sacrifício, Satisfação, Partes do sacrifício, Aniquilação, Salvação

ABSTRACT This work develops the theme of History in Pascal's thought through the theological notion of sacrifice. In Pascal's works, History is relevant only as Spiritual History, the history of salvation of the men that God has chosen among the sinners. As such, History cannot be guided by ordinary temporality, but only by graces temporality, that directs every single instant to the central point: the sacrifice of Christ. Because of that, men only have hope of salvation as long as they integrate Christ's holy Body that continues in sacrifice since the beginning until the end of Time.

* Professor do Departamento de Filosofia da Universidade de São Paulo. Artigo recebido em jan./2003 e aprovado em set./2003.

1 Este trabalho teve o apoio da Fapesp.

KRITERION, Belo Horizonte, $n^{\circ}$ 109, Jun/2004, p. 7-31 
Key-Words History, Sacrifice, Parties of the Sacrifice, Annihilation, Salvation

\section{Satisfação e sacrifício}

A noção de sacrifício, bem como sua relação com a história, deve situarse entre as noções de redenção e pecado. Mas, antes de chegar diretamente ao sacrifício a partir desses dois conceitos, é preciso examinar um outro elo fundamental da cadeia: a noção de satisfação.

Deus teria podido, sem exigir nenhuma satisfação, restabelecer o homem em todas as prerrogativas do estado de inocência, conferir-lhe mesmo privilégios mais notáveis e de uma ordem superior: teria sido mais que uma restauração ou uma nova elevação, mas não uma redenção. $\mathrm{O}$ que caracteriza a redenção é o pagamento do preço pela mas não uma redenção. O que caracteriza
dívida contraída, do resgate pelo cativo. 2

Deus, na sua infinita liberdade, poderia escolher outras vias para reparar a natureza humana, mas então não se trataria de redenção e sim de uma liberação da dívida. Por um lado, o preço a pagar seria anulado. Entretanto, por outro lado, o Deus ofendido não teria o seu pagamento de justiça e a natureza humana não seria elevada como de fato foi.

No seu sentido mais geral, a palavra "satisfazer" significa fazer o bastante para alcançar um objetivo moral, para responder a um anseio, observar uma lei ou poder dar por cumprida uma obrigação ou encargo. $\mathrm{O}$ direito romano usava o termo para dívidas ou ofensas: "[...] satisfazer, nesta matéria, era fazer o bastante para que o credor consentisse em solver uma parte ou o todo da dívida, para que o ofendido renunciasse a vingar-se ou a prosseguir o castigo pela injúria recebida." 3 Embora a noção teológica de satisfação só se tenha constituído plenamente com Santo Anselmo (cf. Cur Deus homo, II, 11), já aparece nas Escrituras e nos Padres da Igreja a idéia de que Cristo entregou-se em

2 HUGON. Le Mystère de la Rédemption, p. 9.

3 SATISFACTION. In: VACANT; MANGENOT (Dir.) Dictionnaire de Théologie Catholique, col. 1135.

" que não rende a Deus a honra devida tira de Deus o que é seu, e o desonra; e isto é pecar. E enquanto não solve o que mais do que tirou pois assima E não basta apenas devolver o que foi tirado, mas, por causa da injúria feita, deve devolver por car algo a mais por causa da injúria feita, assim também, a quem viola a honra de alguém, não bastará que renda a honra, mas deverá compensar a moléstia que causou ao outro com algo que agrade a ele. Cumpre também atentar que quando alguém solve o que injustamente tirou, deve dar algo que não the poderia ser exigido se não tivesse roubado o outro. Logo é assim que todo aquele que peca deve solver a honra que tomou a Deus; e esta é a satisfação que todo pecador deve dar a
Deus". S. ANSELMO. Por qué Dios se hizo hombre, I, t. 1, p. 775 . "compensação" a nossos pecados, no nosso lugar, o que implica a satisfação. Além disso, a noção é valiosa porque evidencia o vínculo de necessidade que une a redenção ao sacrifício, e por isso julgamos importante expô-la, em que pese o fato de Pascal afastar-se da Escolástica em nome da tradição agostiniana. Na verdade, o próprio Pascal nos autoriza a dar tal passo: "Para salvar seus eleitos, Deus enviou Jesus Cristo para satisfazer sua justiça, e para merecer de sua misericórdia a graça da Redenção". ${ }^{5}$

De qualquer forma, é possível dizer que a noção de satisfação já está implícita no próprio Agostinho. Quanto a isso, veja-se sua exposição da ordem divina que exige manutenção irrestrita da justiça:

Como ninguém é capaz de abolir as leis do Criador todo poderoso, por isso a alma não pode deixar de pagar o que deve. Ou paga sua dívida usando bem o dom que recebeu, ou paga-a com a privação do dom de que preferiu abusar. Portanto, se não paga fazendo justiça, paga sofrendo sua desgraça, já que ambas as palavras, justiça e desgraça, encerram a mesma idéia de dívida [...].

A colocação do problema nesses termos explicita a necessidade da satisfação, ou seja, um ato humano em honra a Deus, o qual seja proporcional à ofensa contra Ele feita. A ordem divina assim o exige.

Vejamos a natureza do pecado de Adão. Como criatura, Adão era um ser finito, ontologicamente inferior a Deus e por isso, do ponto de vista ontológico, capaz apenas de atos finitos. Tal foi o pecado original, um ato ontologicamente finito. Em princípio, poderíamos dizer que um outro ato humano, logo finito, poderia compensar o pecado de Adão. Contudo não se pode julgar a ofensa apenas do ponto de vista do agressor. O pecado foi contra o Ser puro, Deus, infinitamente superior ao homem e criador de todo o universo. "A ofensa é proporcionada ao valor da pessoa ultrajada, ou seja, a sua dignidade. Se a dignidade é infinita, a ofensa também o é, como a injustiça seria infinita se o objeto roubado ou destruído tivesse um preço infinito."

Assim se compreende como o pecado original foi infinito. Não por uma infinitude ontológica do ato em si, mas pelo infinito alcance moral que teve esse ato, dando-lhe conseqüências ontológicas que arruinaram a condição humana como um todo. A queda, além de tirar do homem a bem-aventurança, separa-o da esfera da divindade, à qual aderia perfeitamente antes do pecado. A mediação com a infinitude não se fazia necessária porque o homem, criado à imagem e semelhança de Deus, estava unido à infinitude e por isso, de certa

5 PASCAL. Escritos sobre a Graça. In: OEuvres complètes. p. 318 6 S. AGOSTINHO. Del libre albedrí, III, 15, 44. In: Obras de San Agustin. t. 3, p. 395.
7 HUGON, op. cit., p. 37. 
forma, a possuía como a um bem. Com a queda e a conseqüente perda do bem infinito, o homem sentiu por inteiro o abismo ontológico entre criador e criatura, radicalizado pela corrupção da natureza humana, que se espalhou por toda a posteridade. Porém, é pelo alcance moral infinito da ofensa, mais do que por suas conseqüências no homem, que a satisfação se vê comprometida. O pecado original, bem como todos os pecados posteriores, é infinitamente desproporcional a qualquer compensação que o homem venha a dar. Afinal, se o homem consegue sair do plano meramente humano e finito na ofensa, não o consegue mais na reparação. Esta nunca se eleva ao plano divino, mantendose na ordem do ser criado.

Aqui vale o adágio: Honor est in honorante, injuria in injuriato; a honra se mede pela pessoa que homenageia e a ofensa pela pessoa ofendida. Um conde se apresenta diante do Soberano Pontífice para render-lhe homenagem; um rei vem com o mesmo propósito. Os atos de submissão e respeito são os mesmos, a pessoa honrada é a mesma; a homenagem rendida é da mesma ordem nos dois casos? Certamente não. 8

No ideário romano, a noção de dignitas situava-se mais na esfera política do que na moral. "Está ligada ao exercício de cargos importantes na res publica, como o de cônsul ou de senador. No Da Invenção, Cícero define-a deste modo: a dignitas consiste numa autoridade honesta, que merece homenagens, honrarias e respeito." 9 integridade de caráter está excluída da noção, que toma assim um acento totalmente exterior que a faz inacessível aos que não a receberam. Portanto, quando o Cristianismo infinitiza esta noção ao aplicá-la a Deus, não só radicaliza a inacessibilidade própria da dignitas, como coloca sérios problemas para a realização da satisfação. Para que seja satisfação de condigno (usando outra distinção escolástica que nos parece bastante pertinente para a explicação do problema), ou seja, para que possa garantir a proporcionalidade entre a gravidade da falta e a reparação exigida, a satisfação deve prover uma homenagem tão infinita quanto o foi a ofensa a um Ser de dignidade infinita. ${ }^{10}$

\section{HUGON, op. cit., p. 37}

9 PEREIRA, Estudos de história da cultura clássica, v. 2, p. 339

Embora com termos diversos, tais preocupações já haviam aparecido em Agostinho: "Há alguns que nos perguntam: Faltou a Deus outro modo de libertar o homem da miserável condição de sua mortalidade? Somente pôde realizá-la e, como mortal, sofresse a morte? Seria pouco refutá-los dizendo que esse modo pelo qual Deus dignou-se libertar-nos por meio do Mediador entre Deus e os homens, Cristo Jesus, é bom e conveniente à dignidade divina. E seria ainda pouco responder-lhes que não faltaram outros modos possíveis a Deus a cujo poder estão submetidas todas as coisas. No entanto, devemos demonstrar-hhe que rano havia enen convina que houvesse outro processo mais adequado para curar nossa miséria". S. AGOSTINHO. A Trindade, XIII, 10, p. 413
Antes do exame dessas dificuldades, porém, é importante lembrar qual é o ato que se destina, chegando ou não a bom termo, a realizar tal homenagem: o sacrifício.

Queres aplacar Deus? Conhece o que hás de fazer para que Deus se agrade de ti. [...] Continua lendo e escuta: $O$ sacrifício para Deus é um espírito contrito. Deus não despreza um coração contrito e humilhado. Rejeitadas as coisas que oferecias, encontraste o que deves oferecer. Oferecias, ao estilo dos patriarcas, vítimas animais, que eram chamadas sacrifícios. Se tivesses querido um sacrifício, eu o teria certamente dado (Salmo 50). Logo não buscas aqueles sacrifícios e contudo buscas um sacrifício. "

Mas poder-se-ia então indagar qual é a amplitude deste sacrifício: "O sacrifício mais glorioso, mais excelente que lhe possa ser oferecido é o de nós mesmos, sua Cidade, e é este o mistério que celebramos em nossas oblações".'

Pascal, como veremos, trilhará o caminho aberto pelo mestre Agostinho, vendo no sacrifício do cristão o preço da redenção, a ponte entre a miséria penal do homem decaído e sua reparação:

Nós temos esta admirável vantagem de conhecer que verdadeira e efetivamente a morte é uma pena do pecado, imposta ao homem para expiar seu crime, necessária ao homem para purgá-lo do pecado; que é a única que pode livrar a alma da concupiscência dos membros, sem a qual os santos não podem viver neste mundo. Sabemos que a vida, e a vida dos Cristãos, é um sacrifício perpétuo que só pode ser concluído pela morte.

\section{O sacrifício no século XVII: Condren e Pascal}

O oratoriano Padre Charles de Condren ${ }^{14}$ é considerado o grande doutor do sacrifício da escola francesa de espiritualidade. Embora precedido por alguns autores que contribuíram para o tema, como Bérulle, pode-se dizer que Condren lançou as bases da doutrina do sacrifício no século XVII francês. Entre suas contribuições originais destaca-se a doutrina das partes do sacrifício, que retoma as descrições dos sacrifícios do Antigo Testamento renovando-as pelo parâmetro crístico. Essa doutrina, com algumas variações, aparece na Carta sobre a morte do Pai, de Pascal, na qual o autor apresenta suas idéias

11 S. AGOSTINHO, Sermones, XIX, 3. In: Obras de San Agustin, 1981, tomo 7, p. 301.

12 S. AGOSTINHO, City of God, XIX, 23, p. 889

13 PASCAL. Carta sobre a morte do Pai. In: OEuvres completes, p. 276.

Sorbonne no ano seguinte, entra no Oratório em 1617 sucedendo a Bérulle na direção dessa congregação em 1629. 
sobre o sacrifício cristão. Por isso a comparação com a doutrina de Condren poderá esclarecer pontos importantes do texto pascaliano.

Em Condren, a necessidade do sacrifício é uma verdade primeira. O sacrifício é o dever religioso por excelência. A religião parece não visar senão à honra do Criador e o sacrifício é sua expressão perfeita e total. "O próprio do sacrifício é render honra a Deus, e a maior honra que lhe possa ser rendida por uma criatura". ${ }^{15}$ Como também dirá Pascal, a vida do cristão é um sacrifício contínuo, mas para o oratoriano a prioridade do sacrifício é mais radical, colocando-se mesmo acima do amor:

O sacrifício é o primeiro dever que a criatura é obrigada a render a Deus. Este dever parece mais antigo que o do amor e resulta do próprio dom da existência. Pois a criatura, assim que é produzida, deve a Deus um reconhecimento pelo qual protesta ter Dele o ser; ao passo que se poderia dizer que lhe deve o amor só depois que Ele estabeleceu entre eles um tipo de sociedade, que o amor supõe necessariamente e à qual a condição de criatura não dá nenhum direito.$^{16}$

Os fins do sacrifício são basicamente três: "Nós temos três obrigações de sacrificar ou o sacrifício é estabelecido para três coisas: a primeira para reconhecer Deus e render-lhe homenagem segundo todas as perfeições [...]. 0 sacrifício é para render-lhe ação de graças e o reconhecimento e homenagem de seus dons; para render-lhe o que lhe devemos por nossos pecados e torná-lo propício"." Em termos teológicos, ${ }^{18}$ o primeiro fim pode ser chamado latrêutico, ou seja, expressa a adoração a Deus, reconhecendo seus direitos e seu soberano domínio; o segundo, eucarístico, visando ao agradecimento pelos benefícios recebidos; o terceiro, impetratório, mais propriamente ligado aos deveres decorrentes da queda, pode ser novamente dividido em três objetivos: propiciatório (em relação a Deus, cujo favor nos restitui), expiatório (em relação à culpa, da qual obtém a remissão) e satisfatório (em relação à pena e à dívida, das quais é o resgate). Condren mostra que as três divisões gerais podem ser descobertas no ritual mosaico: ${ }^{19}$ o holocausto significa a adoração, o sacrifício pacífico exprime a ação de graças e o sacrifício pelo pecado visa à expiação. Contudo, o acento de Condren recai sobre para a primeira finalidade, a adoração. A infinitude das perfeições divinas e a adoração que merecem

15 CONDREN, Mazarine, 225. In: GALY, J. Le Sacrifice dans l'École Française de Spiritualité. p. 133. As citações de Condren, quase todas de manuscritos, serão feitas sobretudo a partir do livro de Jean Galy, com a referência da Biblioteca (Oratorio, Nacional, Mazarine etc.) em que se encontra o manuscrito. 16 CONDREN, L'dée du sacerdoce et du sacrifice de Jésus Christ.

17 CONDREN, Oratório, 1. In: GALY, op. cit., p. 134

18 Para esta nomenclatura, seguimos HUGON, op. cit., p. 114. terão um destaque tanto maior porque conduzem diretamente, na visão de Condren, à aniquilação contida no sacrifício.

A primeira das perfeições divinas é a Santidade, que em nada aproxima Deus dos homens, mas, ao contrário, é o que os afasta infinitamente. Essa perfeição torna Deus tão grande, santo e retirado a si mesmo que, para reconhecer Sua grandeza e declarar que não é digna de que Deus a olhe, a criatura é destruída e consumida em Sua presença. Para Condren, não se deve estranhar que a Santidade exija a destruição dos efeitos de Sua potência pois tal potência já fora honrada pela criação, enquanto a Santidade o será pelo sacrifício. A vítima tomará o lugar do universo, que deveria ser destruído em si mesmo, para Deus, mas será destruído nela. Essa mesma Santidade levará Condren a uma concepção muito particular de Corpo Místico, no qual os membros se aniquilam no Todo sem se acrescentar propriamente a Ele:

[...] nessa posse que o Espírito Santo toma dos homens, que são membros de Jesus Cristo, ele permanece tão santa e puramente ele mesmo, sem nunca sair de si, sem adição ao que ele é, sem distração do que ele é, porque aplicando-se aos homens aniquila-os em sua própria aplicação, e assim sua aplicação de tal modo é santa e nada pode sofrer de criado nem nada suportar senão sua própria pureza, que consome a própria aplicação ${ }^{20}$

Para Condren, este encontro do infinito com o finito que se dá quando o homem é tomado pelo Espírito Santo serve de paradigma para o sacrifício cristão. $\mathrm{O}$ autor toma o que seria para a tradição uma atitude moral de renúncia e transforma-a em aniquilação radical, entendida não metafórica ou moralmente, mas com todo rigor ontológico. Condren deixa de lado as complicações práticas que podem advir dessa posição, em nome de uma compreensão sem concessões de suas conseqüências ontológicas.

A segunda perfeição divina honrada pelo sacrifício é o Soberano Domínio que tem Deus sobre a vida, a morte e o ser em geral. Embora parta da teoria tomista das causas, Condren reduz ao máximo a ação das causas segundas, fazendo de Deus o único autor do ser. Disso deduz mais uma vez a necessidade de destruição da criatura para reconhecer, desta feita, o império divino. Ao negar-se como agente e produtora de ser, a criatura reconhece seu nada e manifesta maximamente a grandeza do Deus criador e seu poder absoluto sobre a criação. "Matando a vítima e destruindo seu ser, protestava-se que Deus era a fonte de todo o ser e que tinha poder absoluto sobre toda criatura, já que em consideração a Ele destruímo-la". 21 
A terceira perfeição divina honrada é a Plenitude, ou seja, a total suficiência de Deus. Ainda que Condren defenda, em certas circunstâncias, a possibilidade de sermos úteis para a Igreja e para a obra divina em geral, por outro lado é incisivo ao destacar nossa inutilidade diante da perfeição de Deus. A aniquilação agora tem o papel de reconhecer que Deus se basta e que nenhuma criatura lhe é necessária: "[...] todas as coisas são inúteis e Ele não tem necessidade senão de si mesmo já que quando lhe oferecemos alguma coisa destruímo-la como inútil àquele que possui tudo em si mesmo". 22

Tal destaque para a função latrêutica permite a Condren insistir que o sacrifício é um dever essencial à criatura, em qualquer estado em que se encontre. No paraíso, por exemplo, houve religião, logo também houve sacrifício, dada a indissociabilidade dos dois conceitos. Mesmo sem vítimas consumadas pela morte, já que esta só entrou no mundo pelo pecado, havia sacrifício e destruição, mas de outras maneiras. A necessidade do sacrifício, portanto, funda-se no dogma da criação, não no da queda, e estava já presente no estado de inocência: "Nós lhe devemos obrigações por sua dignidade suprema; em uma palavra, porque é Deus". 23

Pascal, por sua vez, destaca antes de tudo o pecado original. Por isso o aspecto expiatório do sacrifício vem primeiro, como seria de se esperar de um jansenista. Os Pensamentos mostram a força destrutiva do pecado e a inutilidade de especular abstratamente sobre o estado de inocência, com o qual não temos mais nenhuma relação. Também por isso o sacrifício pascaliano, essencialmente expiatório, destacará a ação misericordiosa de Deus ao tornar possível uma via de resgate da dívida. Condren, por outro lado, nunca perde de vista a homenagem à grandeza de Deus, para a qual a expiação se fez apenas acidentalmente necessária. No entanto, ainda que inseparavelmente imiscuída à expiação do pecado, a adoração está também presente no sacrifício pascaliano, em termos que o próprio Condren validaria: "[...I mas a realização (do sacrifício) é a morte, na qual, pela aniquilação da vida, a criatura rende a Deus toda homenagem de que é capaz, aniquilando-se diante dos olhos de Sua Majestade e adorando sua soberana existência, a única que existe realmente". ${ }^{24}$

Em ambos os autores, a aniquilação sacrificial é a homenagem devida à Soberania divina. Só Deus possui verdadeiramente o Ser e é o Criador da vida e do ser criado, sobre os quais tem Soberano Domínio. Deus tem poder absoluto sobre suas criaturas e este direito sem limite vai ao ponto de poder des-
truí-Ias. É por isso que a aniquilação sacrificial manifesta os direitos do Deus Criador. No entanto, e agora é Condren que deve concedê-lo, o pecado altera substancialmente a economia do sacrifício:

[...] ele lhe dá (ao sacrifício) um novo objetivo, a satisfação, que se encarnava na antiga lei sob um tipo próprio, o sacrifício pelo pecado; fazendo entrar no mundo a morte, ele dá à destruição necessária desde a origem uma nova forma (parece mesmo, por um estranho paradoxo, que ele permitiu assim uma realização mais perfeita, uma forma mais expressiva). A esta destruição, enfim, ele dá uma significação mais complexa: ela simboliza doravante a religião não só da criatura mas do pecador.25

Se o pecado, de um lado, impõe uma nova finalidade ao sacrifício da criatura inocente, de outro, torna mais impossível a realização de qualquer das três finalidades. A dificuldade já aparece, para Condren, quando este analisa a natureza da criatura: se a adoração implica sacrifícios para cada uma das perfeições divinas, jamais o homem, como criatura limitada, poderá satisfazer tão infinitas obrigações. Tanto mais porque uma das perfeições divinas é a Absoluta Suficiência, a qual já faz inútil, por princípio, qualquer objeto oferecido em sacrifício. Se nenhuma criatura é necessária a Deus, nenhum ato ou esforço do ser criado lhe pode ser agradável. Por conseguinte, o sacrifício pura-mente humano é menos um culto agradável a Deus do que uma confissão do homem reconhecendo que não pode honrá-lo dignamente, ou seja, testemunha menos a grandeza divina do que a impotência do próprio homem. Além disso, sendo absolutamente santo, Deus não pode suportar nada que não seja Ele mesmo. Sua Santidade exige que um sacrifício digno dele tenha uma hóstia e um sacerdote perfeitamente puros, o que é incompatível com a criatura. O pecado, por sua vez, veio agravar tal impureza: "Ainda que todos os homens fossem obrigados a se oferecer na qualidade de hóstia, não poderiam cumprir tal dever porque o pecado os havia tornado irregulares e imundos, e como o pecado dos homens contaminou as criaturas, não somente os homens não podiam ser oferecidos mas também os animais, que eram considerados imundos". ${ }^{26}$ Pascal é igualmente violento ao apontar a impossibilidade do sacrifício do homem. Para ele, tudo que está nos homens é "abominável" sem Jesus Cristo. Condren, entretanto, além de se ater à incapacidade própria da criatura, é mais explícito que Pascal quanto ${ }_{\mathrm{A}}$. extensão da mancha do pecado a toda a criação e não só ao homem. De qualquer modo, é certo para os dois autores que não pode haver, no r i g o r do termo, sacrifício por parte da criatura sem que

25 GALY, op. cit., p. 157.

26 CONDREN. Oratório, 12-13. In: GALY, op. cit., p. 164 
haja uma prévia santificação sobrenatural da vítima, já que, por si, toda oferta é impura e indigna de Deus.

A misericórdia divina, porém, resolveu as dificuldades através da Encarnação do Verbo: "A excelência desta hóstia suprime as impossibilidades aparentes do sacrifício: nenhuma criatura conta diante da grandeza de Deus, mas o Filho é igual ao Pai. Tudo é inútil a Deus, mas Jesus é o objeto de sua complacência. Tudo é impuro diante Dele, mas Jesus é a Santidade mesma". ${ }^{27} \mathrm{Em}$ Pascal, da mesma forma, o fundamento da religião, religação do abismo humano à grandeza divina, dá-se também mediante o sacrifício de Jesus Cristo encarnado:

553 - [...] Vejo o meu abismo de orgulho, de curiosidade, de concupiscência. Não há nenhuma ligação entre mim e Deus, nem entre mim e Jesus Cristo justo. Mas ele se fez pecado por mim e todos os vossos flagelos recaíram nele. Ele é mais abominável do que eu e, longe de desprezar-me, sente-se honrado de que eu vá a ele e o socorra. Mas ele se curou a si mesmo e com maior razão há de curar-me.

Voltando a Condren, Cristo é apresentado como a única hóstia digna de oferecimento a Deus, tendo "uma capacidade infinita para render a Deus honras infinitas dignas de sua pessoa infinita". ${ }^{28}$ Ao mero homem, Condren, renegando seu antecessor Bérulle, recusa qualquer capacidade para se comunicar com Deus. Em nenhum momento, porém, o autor dissimula o paradoxo envolvido. Ao contrário, radicaliza-o com uma visão essencialmente divina de Cristo. Estranho ao mundo e infinitamente separado dele por seu ser divino, o Cristo condreniano é a antítese da imperfeição essencial da criatura. Esta imperfeição arrasta o homem para o nada, o contato com o divino aniquilando o que já era por si irreal. Por isso o néantisme de Condren é tão surpreendente quando aplicado a Cristo. O depoimento de Amelote, fiel discípulo e biógrafo de Condren, revela a magnitude do sacrifício crístico na visão do oratoriano:

Se a Encarnação é chamada por seu Espírito um aniquilamento da forma de Deus, já que o Filho do Homem não fazia aparecer todas as suas vantagens na época de sua carne, quão maior então é o nada a que se reduziu quando morreu na cruz? [...] Nem as criaturas, nem a vida, nem a morte lhe rendiam toda a reverência possível; e ele uniu o criador à sua obra, o infinito ao finito, a morte à vida, a glória à confusão, e pôs as iniquiidades sobre a inocência, para que da composição da natureza humana e da divina, do ser e do não ser, do tudo e do nada resultasse uma espécie de honra admiravelmente inventada e que da associação de tantos extremos opostos se fizesse um acúmulo todo particular de culto e de religião. O sacrifício de Jesus Cristo é o último

27 GALY, op. cit., p. 167

28 CONDREN. Mazarine, 363. In: GALY, op. cit., p. 168. esforço que fez a divina Sabedoria para formar o artifício de toda a glória que se pode dar ao ser infinito. ${ }^{20}$

O sacrifício de Cristo é o único completo, cumprindo os três deveres de adoração, ação de graças e expiação, os quais os ritos antigos tentavam cumprir separadamente. Na realidade, estes ritos jamais o conseguiriam pois não eram nada além de figuras do Sacrifício Crístico, o único verdadeiro. Diz Pascal: "684 - [...] Se tomarmos a lei, os sacrifícios e o reino pela realidade, não podemos concordar todas as passagens. E preciso pois, por necessidade, que sejam apenas figuras [...]". Assim, como já dizia Agostinho: "Mudaram os signos, mas não a fé. Mudaram os signos com os quais se simbolizava algo especial, mas não mudou o que era significado. $\mathrm{O}$ carneiro, o bezerro, tudo significava Cristo". ${ }^{30}$ Foi o sacrifício de Cristo, e não os antigos, que salvou todos os justos, aí incluídos os do Antigo Testamento: "Estes bons antigos servidores de Deus, no Velho Testamento [...] tinham todos uma fé explícita no Messias que devia vir livrá-los, e principalmente aqueles que faziam sacrifícios. Pois sabiam que aqueles animais que eram mortos para purificá-los não tinham a virtude de limpá-los dos pecados e que representavam uma vítima pela morte da qual deveriam ser sacrificados". ${ }^{31}$ Como se vê, o fato de Condren e Pascal utilizarem o vocabulário da figura para descrever a realidade não faz da figura realidade. Ao contrário, a realidade do sacrifício crístico é que serve de norma para as figuras antigas e futuras, judaicas ou pagãs, do sacrifício. A realização em Cristo é a razão das promessas, e não vice-versa.

\section{Condren e Port-Royal}

A esta altura, cabe perguntar pela viabilidade histórica da aproximação entre Condren e Pascal. Não há dúvida de que a Carta sobre a Morte do Pai tem semelhanças surpreendentes com textos de Condren. No entanto, a aparente fertilidade da aproximação não responde plenamente à pergunta pela influência efetiva das idéias de Condren sobre Pascal, o qual só menciona o oratoriano uma vez e de maneira critica: "Laf. 787: M. de Condren. Não há, diz ele, comparação da união dos santos à da santíssima trindade. J. C. diz o contrário". 32

29 BREMOND, op. cit, p. 366

30 S. AGOSTINHO, Sermones, XIX, 3, op. cit., p. 302.

${ }^{3} 1$ CONDREN, Saint Sulpice, 3. In: POUILLARD, Le père de Condren, le Mystique de l'Oratoire, p. 33.

32 Henri Bremond (op. cit., t. 4, p. 396) precisou a referência de Condren: "Vocês consideram a sociedade das três pessoas divinas, que vivem juntas, no mesmo pensamento, no mesmo querer, no mesmo amor, uma mesma vida e um mesmo ser; elas são sempre uma e outra; elas estão num continuo olhar e repouso uma 
Jean Mesnard, na sua introdução à Carta de Pascal, destaca a semelhança das concepções de sacrifício dos dois autores, embora considere pouco provável que Pascal tenha conhecido pessoalmente o oratoriano, falecido em 1641. Pascal também não deve ter tido contato direto com os escritos de Condren sobre o sacrifício, que só foram publicados conjuntamente em 1677, numa compilação devida a Quesnel, L'Idée du sacerdoce et du sacrifice de Jésus Christ. Entretanto, continua Mesnard, Pascal certamente esteve em contato com fervorosos discípulos de Condren e, mesmo que isso não tivesse ocorrido, a influência condreniana o teria alcançado de dentro do próprio meio jansenista, através das Lettres Chrétiennes et spirituelles de Saint-Cyran e da influência deste na abadia.

O início do contato de Saint-Cyran com Port-Royal deveu-se, em parte, à influência de Condren na abadia. A partir de 1625, o bispo de Langres, Sebastien Zamet, tomou-se diretor espiritual de Port-Royal. Ligado ao Oratório, Zamet aproximou as religiosas de pessoas como Bérulle e Condren, sendo que este último substituiu Zamet na direção espiritual de Mère Agnès Arnauld durante o outono de 1626. Fortemente influenciada pelo néantisme de Condren, ela escreverá, a pedido deste, o Chapelet Secret du Saint Sacrement, opúsculo com dezesseis atributos do Santíssimo Sacramento que revelavam as disposições de rebaixamento e aniquilação em que Mère Agnès se encontrava diante do Santíssimo. A irmã não cita a problemática do sacrifício, mas retoma outros aspectos do condrenismo ao voltar-se quase unicamente à essência divina presente na Eucaristia, e não à humanidade de Cristo. O primeiro atributo, a seguir reproduzido, bastará para mostrar a proximidade de Condren:

Santidade: para que Jesus Cristo esteja no Santíssimo Sacramento de modo a não sair de si mesmo, isto é, que a sociedade que quer ter com os homens seja de uma maneira separada deles e residente Nele mesmo, não sendo razoável que se aproxime de nós, que não somos senão pecado, e mesmo em estado de graça não há nada em nós digno da santidade de Deus, de modo que deveríamos dizer ao Santíssimo o que Pedro dizia a Jesus Cristo: Retirai-vos de nós, Senhor, pois somos pecadores.33

A pequena obra teria sido prontamente esquecida, não fosse o ataque dos jesuítas, que a levaram à condenação por parte de oito doutores da Sorbonne em 1633. Criada a polêmica, a qual atingia tanto as religiosas como Condren, Zamet achou alguém que poderia dar uma resposta à altura dos acusadores: Saint-Cyran. Amigo e interlocutor de Jansenius (de quem conseguiu uma apro-

na outra. Toda sociedade na Terra não é nada em comparação a esta sociedade, e a sociedade dos Anjos e Santos no Céu não merece ser comparada a ela" (Carta 17, apud BREMOND).

33 Apud COGNET. Histoire de Ia spiritualité chrétienne, v. III, p. 465. vação para o Chapelet) e também influenciado por Bérulle e Condren, SaintCyran assumiu a polêmica, que foi uma das mais importantes do período para Port-Royal. É a partir daí que Saint-Cyran toma-se um verdadeiro "salvador" para as religiosas, sendo a principal influência espiritual da abadia, acima de Zamet.

Ora, é praticamente impossível que os ecos da polêmica não tenham chegado a Pascal, e com eles a idéias aniquilacionistas de Condren. Quanto ao sacrifício, é provável que a via de acesso tenha sido as cartas de Saint-Cyran, mas de qualquer modo é certo que o tema continuou no meio port-royalista por muito tempo. Antoine Singlin, primeiro diretor espiritual de Pascal, tratará do tema nas suas Instruções Cristãs (cuja aprovação é de 1671) e Nicole, por sua vez, dirá em escrito de 1751: "A morte de Jesus Cristo faz o cristão ver a necessidade que ele próprio tem de morrer e de sacrificar sua vida a Deus; a indignidade que encontra em sua vida para ser sacrificada a Deus obriga-o a se unir à morte de Jesus Cristo, única que pode fazer a sua ser recebida. Toda a sua vida não deve ser senão uma oblação contínua desta dupla morte [...]". 34

Apesar do silêncio dos comentadores a esse respeito, parece que a problemática do sacrifício, inaugurada no séc. XVII por Condren, tomou-se um lugar comum teológico em Port-Royal, como mostram textos de várias fases do jansenismo. É aceitável, portanto, crer que Pascal, se não leu diretamente, ao menos meditou os temas condrenianos (o que é confirmado pelo rápido comentário do fragmento Laf. 787 já citado) e por isso a consulta ao pensamento do oratoriano é legítima. Vejamos agora se a análise da teoria condreniana das partes do sacrifício pode esclarecer alguns pontos importantes que ficaram à sombra na Carta de Pascal.

\section{As partes do sacrifício}

Em Condren, é a idéia de partes do sacrifício que guia a explicação do sacrifício do Cristo. O fundamento de tal teoria não é metafísico, mas escriturístico. Embora o autor afirme, como continuarão a afirmar os teólogos posteriores, que o sacrifício é uma obrigação natural e que a razão pode descobrir sua forma necessária (a destruição), as alusões freqüentes deixam ver que Condren tem sempre em vista o sacrifício de Jesus e suas figuras bíblicas: "Condren parece, à primeira vista, só ver o sacrifício de Cristo através dos ritos antigos; é apenas aparência; seu objetivo é exprimir, na linguagem do 
Antigo Testamento, a realidade dada pelo Novo. A doutrina das partes do sacrifício, aparentemente fundada apenas nos sacrifícios judaicos, ilustrada por eles, não é construída para eles, mas para o sacrifício de Jesus". ${ }^{35}$ Como Condren, Pascal também busca a verdade do sacrifício e da morte na revelação: "A verdade neles (em Jesus Cristo e nos livros canônicos) está descoberta e a consolação unida tão infalivelmente quanto está infalivelmente separada do

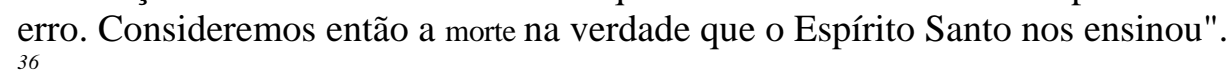

Quanto às partes propriamente ditas, Condren assim as apresenta: a primeira é a santificação da vítima; a segunda, a oblação da vítima; a terceira, a ocisão ou imolação;; a quarta, a inflamação ou consumação; a quinta, a comunhão da vítima. Na Carta, Pascal apresenta uma relação praticamente idêntica: "[...] nos sacrifícios, a principal parte é a morte da hóstia. A oblação e a santificação que precedem são disposições; mas a realização é a morte [...j. É verdade que há ainda uma outra parte, após a morte da hóstia, sem a qual sua morte é inútil: é a aceitação que Deus faz do sacrifício". ${ }^{37}$ Mais à frente, Pascal mencionará também a consumação, portanto só há pequenas diferenças de nomenclatura, não de conteúdo. Ambos tomam tal terminologia explicitamente do Antigo Testamento, mas a referência é sempre o Sacrifício Crístico. Por isso Pascal tenderá, no decorrer da Carta, a assumir também o vocabulário do Evangelho (ressurreição no lugar de consumação, ascensão no de aceitação etc.).

A primeira parte do sacrifício, ou santificação, demanda quatro coisas: primeiramente, a perfeição natural da vítima. No caso de Cristo, ela se dá pela impecabilidade, embora esta vítima compartilhe da semelhança da carne de pecado. ${ }^{38}$ Nos sacrifícios figurativos, a perfeição consistia na ausência de manchas ou defeitos nos animais oferecidos. A exigência de perfeição impunha-se sobretudo porque as imperfeições eram efeitos do pecado original, devido ao qual Deus rejeitava os animais que as tinham. Além, é claro, do caráter profético dessa exigência, que prometia a futura perfeição do Messias:

De sorte que, em todos os séculos que precederam Jesus Cristo, toda a natureza teria permanecido na impotência de testemunhar seu reconhecimento ao criador por este primeiro dever de religião, que é o sacrifício, se Deus não tivesse escolhido alguns animais que quis que fossem vistos como figuras de seu Filho e que fossem ofereci-

35 GALY, op. cit., p. 174 dos a Ele nesta qualidade. Pois, tendo algum sinal ou vestígio do Filho de Deus e representando-o em algo, tinham uma santidade figurativa que os fazia serem chamados animais puros. Eles eram, por este meio, elevados da irregularidade e em seguida oferecidos no lugar dos homens.

A segunda exigência é a consagração que dedica a vítima a Deus, isto é, separa-a de todo uso profano e a faz entrar na ordem do sagrado. E claro que, para tal, é preciso que a vítima abandone sua impureza natural, tornando-se digna de Deus. É aí que surge a terceira exigência: "O sacrifício requer uma santificação sobrenatural, que não se pode fazer por nenhuma virtude ou autoridade humana, mas por autoridade e instituição (divina) que torne a hóstia agradável a Deus acima de sua ordem natural e que lha entregue limpa, que a livre do domínio do homem e da servidão da corrupção". (grifo nosso). Depois desta etapa, a vítima já está obrigatoriamente destinada à imolação, engajamento esse que constitui a quarta exigência, pois a reutilização mundana de algo santificado é sacrílega.

A despeito do engajamento à imolação implicado na santificação, a vítima deve mesmo assim ser formalmente oferecida, o que se dará na segunda parte do sacrifício, a oblação, que aparece nos sacrifícios figurativos através de certas palavras prescritas por Deus para esse fim. Em Cristo, que dispensa tais palavras por ser o próprio Verbo de Deus, a oblação se dá no início da encarnação. Condren separa-a da santificação, ao passo que Pascal praticamente as identifica. Ambos, porém, partem da apresentação paulina do sacrifício em Hebreus, 9, 14 e 10, 5. A este respeito, diz Pascal: "Entrando no mundo, ele disse: "Senhor, os sacrifícios não te são agradáveis, mas deste-me um corpo". Então disse: "Eis-me, venho para fazer, ó Deus, tua vontade, e tua lei é no interior de meu coração". Eis sua oblação. Sua santificação foi imediata de sua oblação." 41

Com a parte seguinte, a imolação ou, como prefere Pascal, a morte da hóstia, inicia-se o essencial do sacrifício: a destruição. "A morte de Jesus rende homenagem à soberania de Deus e satisfação a sua justiça, ao mesmo tempo que salva os homens. Seu lugar no sacrifício é portanto essencial. Se este visa a exprimir os deveres da religião e tornar Deus propício, sua significação e seu efeito são inteiramente realizados pela morte". ${ }^{42}$ Forma necessária do sacrifício, a destruição não dispensa as etapas anteriores, mas estas só existem em função dela e não vice-versa. A vítima é separada da mundanidade e ofere-

39 CONDREN, L'Idée du sacerdoce..., p. 74.

40 CONDREN, Nacional, 237-8. In: GALY, op. cit., p. 179

41 PASCAL, op. cil., p. 276 
cida a Deus para ser imolada. Logo nem a santificação nem a oblação se completam sem a imolação, que constitui o início da destruição da vítima.

Certos teólogos questionam a essencialidade da imolação no sacrifício, destacando a existência de sacrifícios não sanguinolentos, como a missa, para prová-lo. Na verdade, tais sacrifícios pressupõem a vítima já imolada do Calvário e, por conseguinte, não constituem novo sacrifício. A Eucaristia revive a eternidade da oferenda de Cristo e, embora o faça de maneira diferente, não visível, é, contudo, o mesmo sacrifício. Quanto aos sacrifícios antigos não sanguinolentos, tratava-se apenas da parcialidade das figuras, que representavam imperfeitamente a totalidade do sacrifício crístico. Sendo assim, a essencialidade da imolação permanece. Porém, o que nos interessa agora são as opiniões de Pascal e Condren, os quais afirmam explicitamente que a imolação é o principal do sacrifício: Condren diz que as partes precedentes são "condições", Pascal diz que são "disposições"; ambos dão à morte o lugar primordial.

A interpretação contrária é liderada, entre os teólogos cristãos contemporâneos, por Marius Lepin, que renuncia explicitamente à concepção tomista (que também destaca a imolação) para colocar a aniquilação como um dado secundário no sacrifício, subordinado ao caráter, este sim essencial, de doação. Com esse intuito, Lepin busca, como autoridade, justamente Condren, e "citao": "o que agradou a Deus no sacrifício de seu Filho não foram tanto seus jejuns, suores, trabalhos, preces, o dilaceramento de sua carne [...], nem enfim sua própria morte, mas sim a caridade imensa pela qual Ele a ofereceu a Deus perdendo a vida, derramando seu sangue pelos pecadores". ${ }^{43} \mathrm{O}$ problema das referências textuais usadas por Lepin é que se baseiam sobretudo em L'Idée $d u$ sacerdoce, compilação de cujas quatro partes apenas a segunda, como se sabe hoje, foi escrita por Condren, e mesmo esta sofreu alterações do editor. « Ademais, o que supostamente apóia a tese da não essencialidade da imolação é o caráter natural que Condren dá ao sacrifício, o que o estende até o estado de inocência, quando a morte não havia entrado no mundo. Contudo Condren não exclui a necessidade da destruição no sacrifício adâmico, ainda que se desse de outra maneira. Após o pecado, porém, a morte passou a ser condição necessária da destruição, ao mesmo tempo que a função expiatória incorporou-se ao sacrifício. Em resumo, a análise de uma mais ampla gama de textos e a exclusão daqueles falsamente atribuídos a Condren repõem a imolação no centro do sacrifício.
A morte, entretanto, não termina o sacrifício-destruição. A ela deve acrescentar-se a consumação, que corresponde ao fogo que consumia a vítima nos sacrifícios antigos. Isso ocorre porque as perfeições divinas exigem, para além da morte, a destruição inteira do ser. E com esta que se realizam verdadeira-mente as funções antes descritas do sacrifício, que apontavam todas para a aniquilação integral. Nos sacrifícios antigos, a inflamação destruía as imperfeições ligadas ao estado terrestre da vítima, completando a aniquilação sacrificial. A ressurreição, ou inflamação da Nova Lei, é sem comparação mais perfeita, pois a verdade e a glória de Deus realizam o que era figurado pelo fogo, isto é, consomem tudo que era indigno de Deus no corpo de Cristo - a organização do corpo de Adão que restou depois da morte na cruz:

A consumação se completa na ressurreição, pois, assim como nos antigos sacrifícios figurativos daquele de Jesus Cristo as superfluidades e imperfeições da vítima eram consumidas pelo fogo, figura de Deus, do mesmo modo tudo que havia de mortal e passivo em Jesus Cristo, em resumo, tudo que havia nele de Adão, ou seja, a semelhança de nossa carne de pecado, foi consumado pela verdade de Deus [...].

A comunhão, última parte do sacrifício, é representada pela aceitação divina da fumaça nos sacrifícios antigos (Gênesis 8, 21: "Iahweh respirou o agradável odor [...]". ${ }^{46}$ ) Enquanto a consumação termina propriamente o sacrifício, destruindo o estado mundano da vítima, a comunhão é o fruto do sacrifício. A distinção é facilitada no caso de Cristo, pois a ressurreição separase temporalmente da ascensão, a qual corresponde à comunhão (Cristo, como Verbo de Deus, é "comido" pelo Pai, nas palavras de Condren). A ressurreição leva Cristo à perda da vida terrestre e à entrada naquela que lhe é devida como Filho de Deus, ao passo que a ascensão será a fruição dessa mesma vida no seio do Pai, agora com a possibilidade de dar aos homens a graça que não podiam receber antes do sacrifício concluído. Tal quadro, pintado por Condren, tem um correspondente bastante similar na Carta de Pascal:

Assim, estando este sacrifício perfeito pela morte de Jesus Cristo e consumado mesmo em seu corpo por sua ressurreição, em que a imagem da carne do pecado foi absorvida pela glória, Jesus Cristo tinha completado tudo que lhe cabia; restava apenas que o sacrifício fosse aceito por Deus, que como a fumaça se elevava e portava o odor ao trono de Deus, assim Jesus Cristo fosse aceito por Deus, e que, como a fumaça se elevava e portava o odor ao trono do próprio Deus, assim Jesus Cristo fosse, neste estado de imolação perfeita, oferecido, levado e recebido no trono de Deus: e é o que ocorreu na ascensão, na qual ele subiu por sua própria força e pela força de seu Espírito 
Santo que o envolvia por toda parte: ele foi levado como a fumaça das vítimas, figuras de Jesus Cristo, era levada ao alto pelo ar que a sustentava, figura do Espírito Santo.

\section{O cristão e o Cristo}

Em sua Carta, Pascal vai ao sacrifício de Cristo para entender o sacrifício humano. Não é de admirar, já que no homem, para Pascal, tudo que não é Jesus Cristo é abominável. Por isso é como membro de Cristo que o homem será abordado: "[...] e como Deus só considera os homens pelo mediador Jesus Cristo, os homens também só deveriam olhar-se e aos outros mediatamente por Jesus Cristo, pois se nós passarmos pelo meio, só acharemos em nós verdadeiras desgraças ou prazeres abomináveis; mas se considerarmos todas as coisas em Cristo, acharemos toda consolação, toda satisfação, toda edificação". ${ }^{48} \mathrm{Na}$ Carta, Pascal tem como princípio que o que ocorreu a Cristo também deve ocorrer a seus membros, logo a necessidade de reunir-se ao Sacrifício Crístico é evidente.

Condren, por sua vez, tem uma visão semelhante do cristão como membro: "Nossa vida deve ser em Jesus Cristo e nós devemos viver nele como sendo seus membros, pois a graça emanada do mistério da encarnação acarreta nossa incorporação a ele, quer dizer, nos faz ser algo dele, nos faz ser uma porção de sua substância e nos torna subsistentes nele de modo que os cristãos e Jesus não são senão Jesus Cristo, unus Christus, como fala S. Agostinho seguindo S. Paulo, como uma mesma pessoa com Jesus Cristo". ${ }^{49}$ A aparente "generosidade metafísica" desse trecho, que parece dar ao homem o ser de Cristo, não deve, porém, nos enganar: a unificação em Cristo se dá para o cristão como perda e dissolução de seu ser. Se Condren usa a imagem dos membros de Jesus Cristo é para destacar que as disposições das quais o cristão participa são sobretudo disposições de religião, isto é, de honrar a Deus de todas as maneiras, principalmente pelo sacrifício, a maior delas. Em consequiência, a participação no Corpo Místico ${ }^{50}$ será, antes de tudo, participação como vítima no sacrifício do Corpo Místico, e este será o paradigma de compreensão daquilo que deve ser a vida cristã. A morte de Cristo continua através de seus membros e as partes do sacrifício constituirão as etapas da vida do cristão.

O lugar do sacrifício é portanto central na espiritualidade de Condren: Jesus no seu sacrifício compreendeu todos os seus membros; o batismo que os faz entrar na Sua santidade obriga-os a entrar em Seu sacrifício; sua oblação ratifica Sua vontade e os compromete por um novo título à imolação; todos os atos virtuosos da vida cristã são sacrifícios, desde que incluam uma perda ou sofrimento em honra a Deus; a vida inteira ó ́́ no sentido de que deve ser uma morte a si mesmo e uma parte na cruz de inteira ó no sentido de que deve ser una Jesus; a morte enfim é o sacrifício da vida; as provas e a morte consumam o cristão, ou seja, destroem seu ser primeiro em honra a Deus e dão-lhe parte no ser do Cristo ressuscitado. Reconhece-se neste quadro a visão do sacrifício tal como se depreende dos escritos sobre o sacrifício de Jesus; é a mesma concepção de um sacrifício estendido do nascimento à vida eterna, a mesma distribuição das partes, a mesma importância relativa e a mesma significação que Ihes é dada: as duas primeiras preparam o sacrifício, as duas outras o constituem; elas apresentam, inseparáveis, um aspecto rigoroso de destruição total em honra a Deus e um aspecto feliz de participação na vida divina

Em Pascal, igualmente, a vida do cristão será compreendida a partir do modelo do sacrifício de Cristo:

Assim que entramos na Igreja, que é o mundo dos fiéis e particularmente dos eleitos, em que Jesus Cristo entrou no momento de sua encarnação por um privilégio particular ao filho único de Deus, somos oferecidos e santificados. Este sacrifício continua pela vida e se completa na morte, na qual a alma, deixando verdadeiramente todos os vícios vida e se completa na morte, na qual a alma, deixando verdadeiramente todos os vícios imolação e é recebida no seio de Deus. 52

\section{Sacrifício e História}

Como nos propusemos a discutir a questão da História, a pergunta que surge é se este quadro sacrificial da vida cristã pode ser ampliado para toda a história da humanidade, da qual o sacrifício de cada cristão seria uma parte ou, ao menos, uma figura. No caso de uma resposta afirmativa teríamos o Corpo Místico, do início dos tempos até a eternidade, como a grande e única vítima de um sacrifício universal. O ponto de partida seria, mais uma vez, Agostinho: "Toda a comunidade resgatada, ou seja, a assembléia dos fiéis e a sociedade dos santos, é o sacrifício universal oferecido a Deus pelo grande Sacerdote que se ofereceu por nós em sua Paixão, na forma do Servo, para fazer de nós o corpo de uma cabeça tão nobre [...]. Tal é o sacrifício dos Cristãos, que são muitos, formando um só corpo em Cristo"'”. 53

A vantagem dessa hipótese, caso se confirme para Pascal, seria dar à história uma organização própria através das etapas do sacrifício, sem com isso

51 GALY, op. cit., p. 240.

53 S. AGOSTINHO, City of God. X, 6, p. 380 
assumir uma visão progressiva da história, coisa que Pascal recusa prontamente. ${ }^{54}$ Diferentemente da temática das sete idades da história, que sugere prontamente uma pedagogia divina, as etapas do sacrifício não implicam uma progressão, mas os pré-requisitos, a efetivação e os efeitos de um único ato indissociável, o sacrifício do Corpo Místico. Além disso, a hipótese destacaria o caráter expiatório da História e faria de suas etapas não as partes de uma metáfora, mas os constituintes efetivos de um ato real: o sacrifício satisfatório em honra a Deus. Desse modo, a dívida que desencadeia a História constituiria, através da estrutura sacrificial de seu resgate, a própria forma da História.

Então vejamos o que diz Pascal:

[...] que sua graça reine e domine a natureza; e que nossas aflições sejam como a matéria de um sacrifício que sua graça consuma e aniquila para a glória de Deus; e que estes sacrificio particulares honrem e previnam o sacrificio universal em que a natureza inteira deve ser consumada pela potência de Jesus Cristo. Assim nós tiraremos proveito de nossas próprias imperfeições, já que elas servirão de matéria a este holocausto. ${ }^{55}$ (grifo nosso).

Ao que parece, a hipótese é verdadeira, mas a doutrina das partes do sacrifício, que explicitamos com ajuda de Condren, talvez possa acrescentar algo de novo para a concepção de História em Pascal.

É um dos grandes princípios do cristianismo que tudo que ocorreu a Jesus Cristo deve também ocorrer na alma e no corpo de cada cristão: que como Jesus Cristo sofreu durante sua vida mortal, morreu para esta vida mortal, ressuscitou com uma nova vida, subiu ao céu, e senta à direita do Pai; assim o corpo e a alma devem sofrer, morrer, ressuscitar, subir ao céu e sentar à direita.

Todas estas coisas se realizam na alma durante esta vida, mas não no corpo

A alma sofre e morre para o pecado na penitência e no batismo; a alma ressuscita para uma nova vida no próprio batismo; a alma deixa a terra e sobe ao céu na hora da morte e senta à direita no tempo em que Deus o ordena.

Nenhuma destas coisas ocorre no corpo durante esta vida; mas as mesmas coisas se passam em seguida.

Pois na morte, o corpo morre para sua vida mortal; no Julgamento Geral ele ressuscitará para uma nova vida; após o julgamento, subirá ao céu e sentar-se-á à direita. Assim as mesmas coisas ocorrem para o corpo e para a alma, mas em tempos diferentes; e as mudanças do corpo só chegam quando as da alma estão completas, quer dizer, na hora da morte, de modo que a morte é a coroamento da beatitude da alma e o começo da beatitude do corpo. 56

O que salta aos olhos nessa descrição da vivência humana do sacrifício é a defasagem temporal entre o corpo e a alma. Tal fato já aparecia em Condren,

54 A esse respeito, ver BEGUIN, Pascal par lui-même, p. 92.

55 PASCAL, op. cit., p. 278 . que o explicava pela impossibilidade ontológica de o corpo aniquilar-se totalmente neste mundo, visto que não apenas a morte, mas também a ressurreição é necessária para consumar a destruição do corpo. Pascal, por outro lado, apresenta uma explicação de caráter ético: "[...] e S. Agostinho nos ensina sobre este assunto que Deus dispôs as coisas desta maneira de modo ${ }^{57}$ que se o corpo do homem morresse e ressuscitasse para sempre no batismo, não se entrasse na obediência do Evangelho senão pelo amor da vida, ao passo que a grandeza da fé brilha mais quando se tende à imortalidade pelas sombras da morte". ${ }^{58} \mathrm{O}$ caminho para a morte, portanto, é o que constitui a vida do cristão, que do contrário recairia no pecado do orgulho.

Isso pode ser melhor compreendido no interior da teologia jansenista. Ao explicar o pecado original de Adão, que no estado inocente era cheio de glória, imortalidade e inteligência para ver a Majestade Divina, Pascal apela diretamente para o orgulho: "430 — [...] Mas não pôde manter tanta glória sem cair na presunção. Quis tornar-se o centro de si mesmo, independente do meu socorro". Contudo, se consultarmos o Discurso sobre a reforma do homem interior (1640), de Jansenius, certamente lido por Pascal, veremos que o orgulho, como desejo de independência, é o próprio pecado original na interioridade do homem, enquanto o ato de ceder à tentação foi apenas a manifestação exterior do pecado já cometido. Mas Jansenius coloca, entre o pecado de orgulho e o estado de inocência, uma outra mediação:

[...] mas Adão ainda não estava firme neste estado por esta última firmeza que lhe teria feito amar esta sabedoria divina a ponto de esquecer-se de si mesmo, e de esquecer também sua própria grandeza, comparando-a com a grandeza infinita. De modo que, tendo começado a perceber sua felicidade e reconhecer o que ela era, encantou-se de sua beleza, começou a ver-se com prazer, e por este olhar que tornou-o como o objeto de seus próprios olhos desviou sua visão de Deus para voltá-la sobre si mesmo, caiu na desobediência. ${ }^{59}$ (grifo nosso)

A felicidade, portanto, está na origem do orgulho. Mesmo no estado atual, se o homem, ao vencer as outras concupiscências, se deixar levar pela felicidade da vitória, recairá no orgulho. Por isso Deus o pune com a dificuldade em submeter-se à vontade divina: a visão de seus próprios pecados faz o homem ver de quem deve esperar a correção. Devido ao perigo maior do orgulho, os pecados tornam-se remédio. $\mathrm{O}$ apelo a Jansenius, mesmo através de uma mediação não reconhecida explicitamente por Pascal, permite-nos ver qual é a

57 No original: "de peur que".

58 PASCAL, op. cit., p. 278.

59 JANSENIUS. Discours de la Reformation de l'homme intérieur. 
necessidade moral e teológica da defasagem temporal das etapas da alma e do corpo no sacrifício. A simultaneidade poderia trazer felicidade e orgulho, enquanto a defasagem dá espaço às "sombras da morte" por onde o homem se sacrifica sem se regozijar.

Tal explicação adquire nova luz quando lembramos que o sacrifício do cristão é apenas figura do verdadeiro sacrifício, e que por isso deve obedecer à norma imposta por esta realidade superior: se há uma defasagem temporal entre as etapas da alma e do corpo, isso deve explicar-se de algum modo no sacrifício de Deus encarnado.

A alma inicia seu sacrifício no batismo, no qual é santificada, oferecida, imolada, e inicia também sua ressurreição, processo que se completará no instante da morte do corpo, quando a alma ascenderá e será aceita por Deus. Em outras palavras, a vida do cristão, após o batismo, é a consumação da destruição da alma, cujas etapas têm início e fim determinados no tempo. O corpo, contudo, é santificado, oferecido e morto no momento da ascensão da alma e só terá suas etapas concluídas na eternidade. Se observarmos agora o sacrifício de Deus encarnado, veremos que ele tem uma duração determinada que vai do nascimento à ascensão. Onde estaria então a defasagem temporal correspondente àquela existente entre o corpo e a alma do cristão?

Para responder a isso, é importante lembrarmos que Pascal fala de uma defasagem das etapas da alma e do corpo, mas não fala de sacrifícios diferentes. Sendo um só sacrifício, ele deve ter uma só vítima, o cristão, e em conseqüência a defasagem temporal, revelar-se-á apenas uma medida exterior ao ato, não constituindo uma verdadeira cisão. Ora, o que ocorre quando se conclui na ascensão o sacrifício de Deus encarnado? Inicia-se a ação da graça, que percorre toda a duração dos tempos, antes, durante e depois da encarnação, constituindo o Corpo Místico dos eleitos. Uma massa de homens, então, é separada da vida mundana e passa a participar do Corpo Místico, vitalizado pela graça - é a santificação. Veja-se como a concebe Condren:

A Igreja que ele quer salvar por este sacrifício é composta de diversos membros espalhados em todos os séculos desde Adão até o fim do mundo. E por sua vida que ele mereceu esta Igreja, isto é, que para ela mereceu todas as graças que os homens que a compõem já tiveram, têm presentemente e terão até o dia do juízo final. Por sua morte tirou o obstáculo que impedia os homens de receber suas graças porque satisfez à justiça de Deus pelos pecados deles; justiça que, vendo-os antes como criminosos e devedores insolventes, devia puni-los e não lhes dar sua graça. Enfim, por sua ressurreição, ou seja, no estado de sua ressurreição, dá e aplica aos homens a graça que lhes mereceu por sua vida e que os tornou capazes de receber por sua morte. 60
Ao mesmo tempo, a graça faz com que este Corpo, unificado, ofereça-se ao Criador - é a oblação. "É preciso que nossa oblação seja, constante e irrevogável, como a do Filho de Deus. Não nos devemos dar por um tempo a Deus, como fazem tantos, mas nos abandonar a Ele para sempre ${ }^{61}$ Inicia-se agora também a mortificação deste Corpo para honrar o Criador, mas essa etapa só se concluirá no juízo final - é a imolação. "[...] para não mais nos assujeitarmos ao pecado [...] é preciso ainda trabalhar continuamente para destruir o corpo do pecado, destruindo todos os seus membros, e continuando e completando em nós mesmos a morte e o sacrifício que Jesus Cristo ofereceu na cruz, mortificando-nos sem cessar, arruinando pouco a pouco todas as inclinações do pecado". 62

A ascensão de Cristo, portanto, inaugura o sacrifício histórico do Corpo Místico, sem contudo que Cristo se distinga dele. Jesus Cristo é seu Corpo Místico, pois é sua cabeça inseparável e também a vida que o alimenta pela graça. Esta graça só pode agir devido ao sacrifício já concluído do Calvário, mas, como a vítima é a mesma, os sacrifícios são um só. A defasagem temporal reaparece entre Jesus Cristo e seu Corpo Místico, que prossegue para além da Encarnação; porém, como já dissemos, o tempo é apenas um paralelo exterior que não afeta a unicidade do sacrifício.

A bem da verdade, toda história exterior corresponde a essa medida externa do sacrifício, ao passo que este é reconduzido para a interioridade. Entendase: o percurso de imolação do Corpo Místico não é construído pelo corpo exterior de cada cristão (que só se santifica e oferece na morte), mas pela alma, que conclui sua destruição (imolação e consumação) ainda neste mundo. Aniquilando-se, afastando-se do corpo e de si mesma, a alma reintegra o cristão ao Sacrifício Crístico e rende a homenagem devida à soberania divina.

Esse auto-abandono produz a dor que dá à alma a participação efetiva no Corpo Místico. Pascal não é um formalista, logo não pode ver na salvação uma mera "atribuição" de inocência. A satisfação exigida pela Redenção deve ser vivida (ou morrida) por todos em Jesus Cristo, e isso só é possível graças àquela defasagem temporal entre o Cristo encarnado e seu Corpo Místico. Não que a exteriorioridade decorrente da defasagem constitua de alguma maneira o Corpo Místico, mas é em relação a esse exterior que a alma se mutila. Embora a mortificação seja interna, ela vem de uma negação da exterioridade,

61 SINGLIN, Instructions Chrétiennes. t. 5, pág. 51

62 SINGLIN, op. cit., t. 4 , p. 83.0 recurso a Singlin justifica-se por se tratar de um dos expoentes do movimento jansenista, tendo sido diretor espiritual de Pascal inclusive. E certo, portanto, que Pascal conhecia suas idéias, e é provável que as Port-Royal, qualuer forma, os trechos citados sa 
seja do corpo, seja da própria alma, que passa a ver-se como um outro para si mesma e nega-se. Logo, a história exterior da humanidade será, além de medida exterior do sacrifício, o próprio objeto renegado por ele. A história interior, como mortificação expiatória dos cristãos no Corpo Místico, constituir-se-á, portanto, pela negação da história exterior. O cristão integra o Corpo negando-se; a História torna-se o percurso interior do Corpo ao ser negada em sua exterioridade mundana; para o membro ou para o todo, a negação será dolorosa.

498 - É verdade que é preciso penar para participar da piedade. Mas essa dificuldade não vem da piedade que começa a existir em nós, e sim da impiedade que em nós ainda existe. Se os nossos sentidos não se opusessem à penitência e se a nossa corrupção não se opusesse à pureza de Deus, não haveria nisso nada de penoso para nós. Só sofremos à proporção que o vício, que nos é natural, resiste à graça sobrenatural. O nosso coração sente-se dilacerado entre esses esforços contrários. Mas seria bem injusto imputar essa violência a Deus, que nos atrai, em lugar de atribuí-la ao mundo, que nos retém. E como uma criança cuja mãe a arranca dos braços dos ladrões e que deve amar, na dor que sofre, a violência amorosa e legítima de quem procura a sua liberdade, e só detestar a violência e a tirania dos que a retêm injustamente [...].

Essa fratura, sentida como uma mutilação, é na verdade uma "desmutilação" pois, abandonando-se, o homem reencontra sua verdadeira integralidade em Cristo, desfazendo a mutilação do pecado original que o separou de sua própria substância. ${ }^{63}$

Por fim, vale destacar novamente o caráter interior e sacrificial da História em Pascal. O Corpo Místico, conteúdo da verdadeira História, não é estático e nem se move apenas para recrutar os eleitos, mas insere-se num movimento universal de sacrifício que os salvará. Esse movimento é o da destruição sacrificial, etapa essencial do sacrifício. Daí a importância da História no processo de expiação do pecado: negar a existência da História seria negar a possibilidade da real satisfação da dívida, já que a História é o espaço da dor e do sofrimento por meio dos quais o homem constitui efetivamente o Corpo Místico de Cristo e por ele conquista a Redenção.

63 Uma última objeção propriamente teológica deve ser respondida para viabilizar tal visão da história: o batismo, limpando o homem do pecado original, não impossibilitaria o desdobramento histórico da expiação, limitando o sacrifício à estrita duração da Encarnação do Verbo? A teologia jansenista do pecado original pode responder a isso. Hâ uma distinção interna ao pecado original que Jansenius (Augustinus, L. 2, t. 1, cap. 1 e 2) toma de S. Agostinho: o pecado divide-se na culpabilidade do delito (reatus culpae) e nas conseqüências penais deste (reatus poenae). $\mathrm{O}$ batismo anula imediatamente a culpabilidade do homem, mas não as punições decorrentes do crime, as quais não podem desaparecer do que a concupiscência que leva o homem, mesmo batizado, a recair no pecado. $E$ a concupiscencia que garantirá o espaço do que a concupiscência que leva o homem, mesmo batizado, a recair no pecado. E a concupiscencia que garantirá o espaço negar a exterioridade. Se o batismo a anulasse como à culpa, o homem não teria como participar do sacrif́cíc erístico e seri salvo por mera atribuič̃o. Talvez ainda fosse possível falar de Corpo, mas não de um percurso histórico deste Corpo. Em outras palavras, não seria possível falar de Redenção.

\section{Referências}

BALTHASAR, H. v. Théologie de l'Histoire. Paris: Pion, 1950.

BÉGUIN, A. Pascal par lui-même. Paris: Seuil. 1964.

BÍBLIA DE JERUSALÉM. Trad. Do texto em língua portuguesa diretamente dos originais. GORGULHO, G. da S.; STORNIOLO, I.; ANDERSON, A. F. (Coord.). São Paulo: Sociedade Bíblica Internacional/Paulus, 1985.

BREMOND, H. Histoire Littéraire du sentiment religieux en France. Paris: Bloud et Gay, 1935.

COGNET, L. Histoire de la Spiritualité Chrétienne. v. III (La Spiritualité Moderne). paris: Aubier, 1966

CONDREN, C. L'idée du sacerdoce et du sacrifice de Jésus Christ. Paris, 1849. GALY, J. Le Sacrifice dans l'École française de Spiritualité. Paris: Nouvelles Editions Latines, 1951.

HUGON, E. Le Mystère de la Rédemption. Paris: Pierre Téqui, 1922.

JANSENIUS, C. Discours de la Reformation de l'homme intérieur. Trad. de Arnauld d'Andily. Paris, 1644 .

LEPIN, M. L'idée du sacrifice dans la religion chrétienne. Paris: Delhomme et Briguet, 1897.

MERSCH, E. Le Corps Mystique du Christ. Bruxelles: L' Éd. Universelle, 1936.

NICOLE, P. Essais de Morale. t. X . Genève: Slatkine Reprints, 1971.

PASCAL, B. Carta sobre a morte do Pai. In: Oeuvres complètes. Paris: Seuil, 1963. . Pensamentos. São Paulo: Abril, 1979. (Os Pensadores)

PEREIRA, M. H. Rocha. Estudos de História da Cultura Clássica. Lisboa: Fund. C. Gulbenkian, 1984, v. 2. (Cultura Romana).

POUILLARD, C. Le père de Condren, le Mystique de l'Oratoire. Paris: FAC, 1994. S.

AGOSTINHO. City of God. XIX, 23, 6. Londres: Penguin Books, 1984.

Del libre albedr o. In: Obras de San Agustín. 4. ed., t. 3. Madrid: BAC,

Sermones. XIX, 3. In: Obras de San Agustín. t. 7. Madrid: BAC, 1981. A

Trindade. XIII, 10. São Paulo: Paulus, 1994.

S. ANSELMO. Por qué Dios se hizo hombre. In: Obras Completas de San Anselmo. t. 1. Madrid: BAC, 1952 .

SINGLIN, A. Instructions Chrétiennes. Paris, 1736

VACANT, Alfred; MANGENOT, Eugène (Dir.). Dictionnaire de Théologie Catholique. Paris: Etouzey et ané, 1903. (COL. 1135). 